\title{
Correlation between mycorrhizae and the growth of Pinus sylvestris in ploughed sites in northern Finland
}

\author{
HENRY VÄRE
}

\begin{abstract}
Väre, H. 1988: Correlation between mycorrhizae and the growth of Pinus sylvestris in ploughed sites in northern Finland. - Karestenia 28:31-33.

Scots pine saplings were examined in some clear-cut sites in northern Finland. The length of the saplings, the number of annual needle crops and the mycorrhizal infection percentage were recorded in saplings grown in ploughed and unploughed sites in order to reveal 1) the effect of ploughing on mycorrhiza formation and 2) the effect of possible disturbances in mycorrhiza formation on the growth of saplings. The mycorrhizal infection percentage was significantly lower in the double humus layer at ploughed sites than in the undisturbed humus layer at unploughed sites. The mycorrhizal infection percentage showed a significant positive correlation with the length of the saplings and the number of annual needle crops. In injured saplings, in which the length and number of annual needle crops were lowest, mycorrhiza formation was also poorest.
\end{abstract}

Henry Väre, Dept. of Botany, Univ. of Oulu, SF-90570 Oulu, Finland

The clear-cut, ploughed forest sites in northern Finland contain young pine trees, Pinus sylvestris, whose growth has been disturbed in a variety of ways. In some places the trees are obviously debilitated, while in others they are growing vigorously but have lost their apical dominance. The young trees also suffer from a variety of diseases, e.g. Ascocalyx abietina (Lagerb.) Schläpfer, Phacidium infestans Karst. Sudden deterioration in condition and growth often leads to rapid death of the young pines (Tikkanen \& Raitio 1984). These sites were earlier mixed Picea abies, Betula pendula and $B$. pubescens forests.

A series of nutrient analyses performed on needle samples by Tikkanen (1985) enabled formulation of a preliminary hypothesis. The delibitation of the trees was attributed to a deficiency of phosphorus and to some extent of nitrogen, exacerbated by climatic effects. It was suspected that the clear-cutting and ploughing of forest sites could cause a number of disturbances in the soil nutrient balance and this could affect the young trees, chiefly via the chemical properties of the phosphate anion and the significance of this ion for the energy balance of the plant (Tikkanen 1985).
Investigation of light microscopical slides of roots revealed some injuries in the anatomy of short roots, for example thinning of cell walls, and a decrease in the amount of starch granules (Hohtola \& Tikkanen, unpublished manuscript). The study also indicated that the root system was not well developed and that many short roots lacked mycorrhizae.

The aim of the present study was to examine the relationship between the length, the number of annual needle crops, and the mycorrhizal infection percentage of the trees.

\section{Material and methods}

The study areas are situated in the parishes of Kittilä (Rovaselkä 67 $37^{\prime} \mathrm{N}, 24^{\circ} 36 \mathrm{E}$, alt. $240 \mathrm{~m}$ ) and Sodankylä (Ristonmännikkö $67^{\circ} 16^{\prime} \mathrm{N}, 26^{\circ} 08^{\prime} \mathrm{E}$, alt. $265 \mathrm{~m}$ ) and in the rural district of Rovaniemi (Liivakaira $67^{\circ} 06^{\prime} \mathrm{N}, 25^{\circ} 25^{\prime} \mathrm{E}$, alt. $200 \mathrm{~m}$ ).

Root samples were collected from each site from 30 trees. Healthy-looking and injured trees were selected on the basis of the shoot condition. Injured Scots pine saplings had decreased annual growth, 


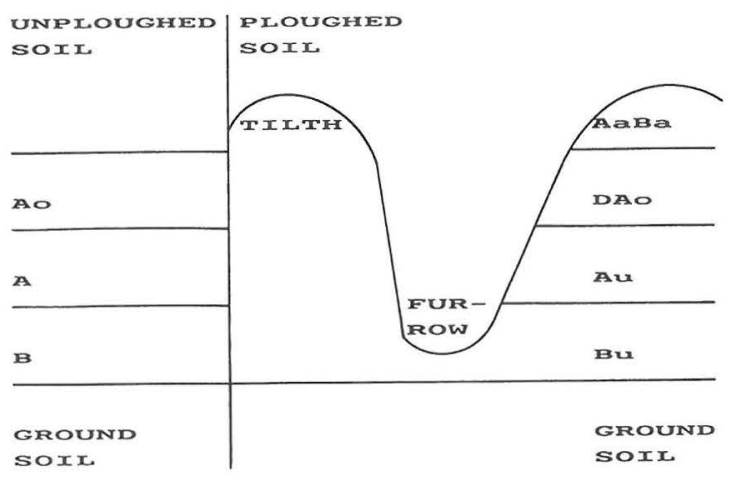

Fig. 1. Schematic illustration of podzolized soil horizons in an unploughed and a ploughed site. $\mathrm{Ao}=$ humus layer, $\mathrm{A}=$ eluvial horizon, $\mathrm{B}=$ illuvial horizon, $\mathrm{AaBa}=$ mixed eluvial and illuvial horizons above double humus, DAo $=$ double humus layer, $\mathrm{Au}=$ original eluvial horizon under humus, original illuvial horizon under humus.

only a few annual needle crops, needles of varying length, and curvy, twisting branches and stems (poor lignification). The length of the trees was measured and the number of annual needle crops was calculated at each site. The mycorrhizal infection percentage was examined in the double humus and undisturbed humus layers (Fig. 1). Roots were collected by following the long root from the beginning of the stem. Pieces of long roots, altogether at least $50 \mathrm{~cm}$, were taken from the humus and double humus layer.

Statistical analysis was performed by ANOVA and a linear regression analysis was used to interpret the relations between the length of the trees, the number of annual needle crops, and the mycorrhizal infection percentage.

\section{Results}

The average length of Scots pine saplings, the average number of annual needle crops, and the average mycorrhizal infection percentage of injured, healthylooking, and control trees are presented in Table 1.

The mycorrhizal infection percentage was significantly smaller $(p<0.001)$ in the double humus than in the undisturbed humus layer. The difference was also significant $(\mathrm{p}<0.001)$ between injured and healthy-looking saplings (Table 1).

The correlations between the length, the number of annual needle crops, and the mycorrhizal infection percentages were significant $(p<0.001)$ in each case (Table 2). The coefficients of determination $\left(\mathrm{r}^{2}\right)$ were not high and between the sapling length and the mycorrhizal infection percentage the coefficient was low $(18 \%)$.

Table 1. The average length, the average number of annual needle crops, and the average infection percentages of injured, healthy-looking, and control trees.

\begin{tabular}{|c|c|c|c|c|c|c|c|}
\hline \multirow{2}{*}{ Tree group } & \multirow{2}{*}{$\begin{array}{c}\text { No. of } \\
\text { samples (n) }\end{array}$} & \multicolumn{2}{|c|}{ Length } & \multicolumn{2}{|c|}{ Annual needle crops } & \multicolumn{2}{|c|}{ Mycorrhizal infection } \\
\hline & & $(\mathrm{cm})$ & S.E. & (no.) & S.E. & (\%) & S.E. \\
\hline Injur & 30 & 148 & 6.5 & 2.3 & 0.09 & 17 & 7.0 \\
\hline Healthy-looking & 30 & $209 a$ & 6.9 & 3.6 & 0.09 & 38 & 12.0 \\
\hline Control & 30 & $220 a$ & 11.6 & 4.0 & 0.15 & 87 & 21.3 \\
\hline
\end{tabular}

Note: Values in the columns followed by the letter ' $a$ ' are not significantly different at $\mathrm{p}=0.05$.

Table 2. Correlations between sapling length, the number of annual needle crops, and the mycorrhizal infection percentages.

\begin{tabular}{lll}
\hline & Length $(\mathrm{cm})$ & No. of annual needle crops \\
\hline No. of annual needle crops & $\begin{array}{l}\mathrm{y}=1.3+0.01 \mathrm{x} \\
\mathrm{r} 2=0.39 * * *\end{array}$ & \\
Mycorrhizal infection (\%) & $\begin{array}{l}\mathrm{y}=155.8+0.78 \mathrm{x} \\
\mathrm{r} 2=0.18 * * *\end{array}$ & $\begin{array}{l}\mathrm{y}=2.4+0.02 \mathrm{x} \\
\mathrm{r} 2=0.43 * * *\end{array}$ \\
\hline
\end{tabular}




\section{Discussion}

The results show that the formation of mycorrhizae is poorer in nursery-grown Scots pine saplings in the ploughed site than in natural saplings in the unploughed site. This may be a consequence of a reduction in the humus layer and alterations in its chemistry, which lead to a deficiency of phosphorus (Tikkanen 1988).

Although the needles were not weighed, the result indicate that the mycorrhizal infection percentages and the length of the trees are associated with the number of annual needle crops. Poor mycorrhizae in the injured roots could result in diminished absorption of nutrients, which may weaken the photosynthetic capacity. It is also possible that the poor formation of mycorrhizae may be a result of injuries in the shoot. This could lead to a diminished flow of carbohydrates to the roots. It is difficult to separate cause from effect.

\section{References}

Hohtola, A. \& Tikkanen, E. (in prep.): Root anatomy of weakened Scots pine saplings on a ploughed site.

Tikkanen, E. 1985: Aurausalueen heikkohuntoisten männyntaimien ravinnetaloudesta Pohjois-Suomessa. Metsäntutkimuslaitoksen tiedonantoja 186:1-23 (Engl. abstr.)

- 1988: A hypothesis on the cause of abnormal development in Scots pine saplings on ploughed sites in northern Finland. - In: Murray, M. (ed.), Proceedings of the workshop on forest regeneration at high latitudes, Sweden, in 1985. USDA General Technical Report (in press).

Tikkanen, E. \& Raitio, H. 1984: Pohjois-Suomen männyntaimien epänormaali kehitys ja olettamus sen syistä. - Metsäntutkimuslaitoksen Tiedonantoja 165:1-27. (Engl. abstr.)

Accepted for publication

on 10 June, 1988 